\title{
Response Analysis of Stimulating Efficacy of Polihexanide in an in vitro Wound Model with Respiratory Ciliary Epithelial Cells
}

\author{
C. Roth ${ }^{a} \quad$ A.G. Beule ${ }^{a} \quad$ A. Kramer ${ }^{\text {b }} \quad$ W. Hosemann ${ }^{a} \quad$ T. Kohlmann ${ }^{c}$ C. Scharfa \\ ${ }^{a}$ Department of Otorhinolaryngology, Head and Neck Surgery, ${ }^{b}$ Institute of Hygiene and Environmental Medicine, \\ and ${ }^{C}$ Institute of Community Medicine, Ernst Moritz Arndt University Greifswald, Greifswald, Germany
}

\section{Key Words}

Polihexanide $\cdot$ Wound model $\cdot$ Respiratory ciliary epithelial cells $\cdot$ Wound healing $\cdot$ Wound stimulation

\begin{abstract}
In animal wound models, accelerated wound closure has been shown by use of polihexanide applied in antimicrobially effective concentrations. Additionally, an increased ATP production of keratinocytes in vitro induced by polihexanide was demonstrated and interpreted as a stimulatory effect on cell proliferation. Based on these results and the clinical reports on improved wound healing after introduction of polihexanide for preoperative antisepsis in the nasal cavity, polihexanide was tested in a wound model on respiratory ciliary epithelial cells allowing measurement of the healing process after artificial injury. $0.5 \mu \mathrm{g} / \mathrm{ml}$ polihexanide accelerated wound healing in terms of proliferation and migration significantly after an exposure time of 1 and $96 \mathrm{~h}$. At a concentration of $1 \mu \mathrm{g} / \mathrm{ml}$ polihexanide, the stimulation of wound healing was significantly increased only after an exposure time of $96 \mathrm{~h}$. This is the first study to demonstrate acceleration of wound healing in a standardized in vitro model using an epithelial cell line. Considering the present results and previous reports on the impact of polihexanide on wound healing, the conclusion is drawn that the positive effect of polihexanide on wound healing is a separate, dosedependent effect independent of its antiseptic properties.
\end{abstract}

Copyright $\odot 2010$ S. Karger AG, Basel

\section{KARGER}

Fax +4161306 1234

E-Mail karger@karger.ch

www.karger.com
2010 S. Karger AG, Basel

$1660-5527 / 10 / 0237-0035 \$ 26.00 / 0$

Accessible online at:

www.karger.com/spp

\section{Introduction}

Polihexanide is the only antiseptic promoting wound healing used at antimicrobially relevant concentrations in experimental animal models. A dilution of $0.02 \%$ polihexanide in polyethylene glycol 4000 and Ringer has shortened the duration of wound healing, defined as wound closure and based on histological findings, in artificial wounds in guinea pigs [1] and in a higher concentration of $0.04 \%$ in piglets using a double-blind, randomized, stratified, controlled parallel-group design [2].

To confirm these observations, different in vitro studies were performed: on separated peritoneal explants, a positive trend towards an increased growth rate of the explants was found only for Taurolin Ringer at a concentration of $0.5 \%$ [3]. However, Taurolin Ringer is antiseptically effective only after a long exposure time $(>6 \mathrm{~h})$ and recommended for peritoneal lavage, but not for wound antisepsis. Also ethanol increased the growth rate of peritoneal explants, but only at a concentration of $10 \%(\mathrm{v} / \mathrm{v})$, with no antimicrobial effect at this low concentration [4]. Used in an antimicrobial concentration of $70 \%(\mathrm{v} / \mathrm{v})$, the growth rate of peritoneal explants was partially inhibited in the same manner as by polihexanide in $0.02 \%$ dilution $(200 \mu \mathrm{g} / \mathrm{ml})[3]$.

Using lower concentrations of polihexanide $(0.2,0.4$ and $1 \mu \mathrm{g} / \mathrm{ml}$ ) the ATP production of keratinocytes sig-

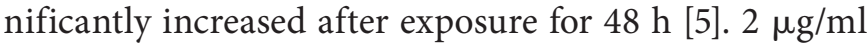
induced only a small increase in ATP production, where- 
as $\geq 4 \mu \mathrm{g} / \mathrm{ml}$ inhibited ATP production significantly. After an exposure time of $24 \mathrm{~h}$, a similar effect was achieved but did not reach statistical significance. The increase in ATP production was interpreted as a stimulatory effect on cell proliferation [5]. In $\mathrm{HaCaT}$ cells using identical concentrations of polihexanide, no influence was detected [5]. Using a stimulating concentration for keratinocytes $(0.2-$ $1 \mu \mathrm{g} / \mathrm{ml}$ polihexanide) the production of IL-6 in $\mathrm{HaCaT}$ cells was markedly decreased, whereas using concentrations of $>2 \mu \mathrm{g} / \mathrm{ml}$ the production of IL- 6 was increased in a time-dependent manner [5]. This may explain the clinically observed anti-inflammatory efficacy of polihexanide by some authors [6-8]. In co-culture of keratinocytes and Staphylococcus aureus at a concentration of $1 \mu \mathrm{g} / \mathrm{ml}$, polihexanide completely inhibited bacterial growth, whereas cell growth was not impaired [9]. This is confirmed by the favorable biocompatibility index of polihexanide [10].

After introducing polihexanide instead of Octenisept for preoperative antisepsis in the nasal cavity in the department of ENT at the University of Greifswald, improved wound healing was observed compared to the previously used antiseptic. For this reason, polihexanide was tested on respiratory ciliary epithelial cells with the following aims: (a) to use an in vitro wound healing model [8] instead of the previously used monolayer culture method [5], allowing a simulation of cell proliferation after artificial injury closer to reality, (b) investigating whether the stimulating efficacy of polihexanide on keratinocytes is similar for respiratory ciliary epithelial cells, and (c) if the wound healing effect of polihexanide is dosage-related. After identification of the concentration with the highest stimulating efficacy, studies need to investigate the mode of action.

\section{Materials and Methods}

\section{Wound Model}

An in vitro wound model modified according to Beule et al. [11] was used. S9 epithelial cells in their 18th passage were seeded at a density of $10^{5}$ cells/well on a 6-well tissue culture plate (Sarstedt; Newton, N.C., USA) and grown in minimum essential medium without L-glutamine (MEM Earl; PromoCell, Heidelberg, Germany) containing $4 \%$ fetal calf serum, $2 \%$ glutamine and $1 \%$ nonessential amino acids. At confluence, 3 wound areas per well were created using a $4 \mathrm{~mm}$ sterile biopsy punch (pfm AG, Cologne, Germany) and cells were flushed away by an Eppendorf pipette. Figure 1 depicts an example for started wound healing. For quality control, resulting wounds were controlled and documented microscopically ( $\times 4$ optical magnification; Nikon Eclipse; Nikon, Tokyo, Japan).

Two experiments were performed after wounding.

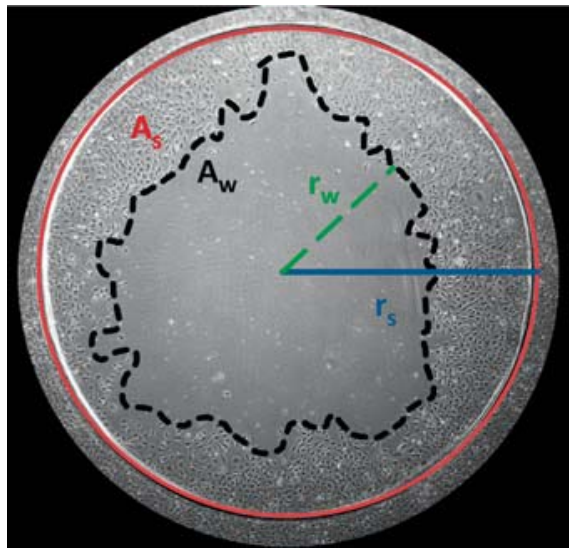

Fig. 1. Schematic description of wound measurement. $r_{w}=$ Radius of the minimal diameter of the wound; $r_{s}=$ radius of punched circle; $A_{w}=$ wound area related to the defined punched area $A_{s}$.

- In experiment 1 , polihexanide was tested at a concentration of $32,16,8,4,2,1,0.5,0.25,0.125$ and $0.0625 \mu \mathrm{g} / \mathrm{ml}$, respectively, and compared with an untreated control. All cells were exposed to polihexanide for $96 \mathrm{~h}$.

- In experiment 2, the two most effective concentrations identified in experiment $1(0.5$ and $1 \mu \mathrm{g} / \mathrm{ml})$ were tested in 5 setups: (a) $0.5 \mu \mathrm{g} / \mathrm{ml} / 1 \mathrm{~h} /$ medium exchange $48 \mathrm{~h}$; (b) $0.5 \mu \mathrm{g} / \mathrm{ml} / 96 \mathrm{~h} /$ medium exchange $60 \mathrm{~h}$; (c) $0.5 \mu \mathrm{g} / \mathrm{ml} / 96 \mathrm{~h} /$ medium exchange $48 \mathrm{~h}$; (d) $1 \mu \mathrm{g} / \mathrm{ml} / 1 \mathrm{~h} /$ medium exchange $48 \mathrm{~h}$; (e) $1 \mu \mathrm{g} / \mathrm{ml} /$ $96 \mathrm{~h} /$ medium exchange $60 \mathrm{~h}$. The medium exchange included removing the medium from the cells and covering the cells with new medium without polihexanide after $1 \mathrm{~h}$ of incubating; during an exposure of $96 \mathrm{~h}$, the medium exchange was combined with addition of polihexanide.

After $0,12,24,36,48,60,72,84$ and $96 \mathrm{~h}$, wound areas were digitally recorded (example of time course of wound healing shown in fig. 2). For each wound, the radius $\left(r_{w}=\right.$ radius of the minimal diameter of the wound) and the wound area $\left(A_{w}\right)$ were measured related to the defined punched area $\left(A_{s}\right)$ at $t_{0}(12.57$ $\mathrm{mm}^{2}$ ) and the defined radius $\left(\mathrm{r}_{\mathrm{s}}=\right.$ radius of punched circle, $2 \mathrm{~mm}$ ).

\section{Test Agent}

Test agent was Cosmocil (20 g polihexanide in $100 \mathrm{~g}$ sterile distilled water; B. Braun Medical AG Sempach, Switzerland, Charge No. 0000 695544).

\section{Cell Line}

The following cell line was used: epithelial immortalized human S9 (JHU-53) ATCC CRL-2778TM with immortalized adenovirus 12 and SV40 virus hybrid (origin bronchus in cystic fibrosis), cultivated in MEM Earl growth medium, containing $4 \%$ fetal calf serum, $2 \%$ glutamine and $1 \%$ non-essential amino acids, $95 \%$ air $+5 \% \mathrm{CO}_{2}$ at $37^{\circ} \mathrm{C}$ in Cell ${ }^{+} 6$-well tissue culture plates (Sarstedt, Nürnbrecht, Germany). The steps of subculture included:

(1) removal of culture medium;

(2) brief rinse of the cell layer with $0.25 \%(\mathrm{w} / \mathrm{v})$ trypsin- $0.53 \mathrm{mM}$ EDTA solution to remove all traces of serum which contained trypsin inhibitor; 

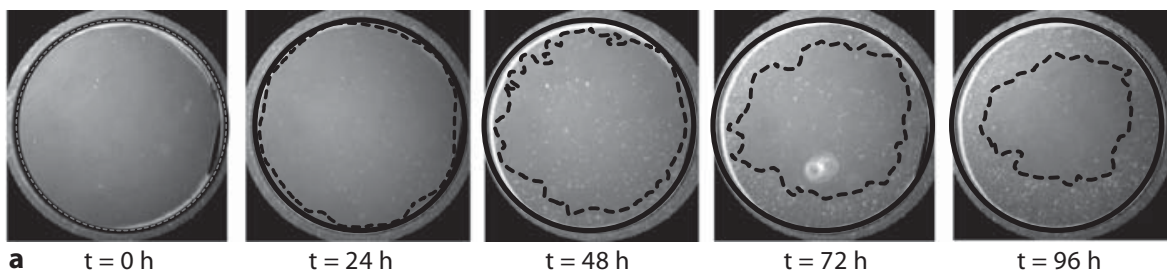

Fig. 2. Progress of wound healing. a Poli-

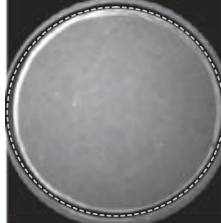

b $\quad t=0 h$

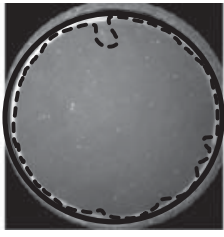

$\mathrm{t}=24 \mathrm{~h}$

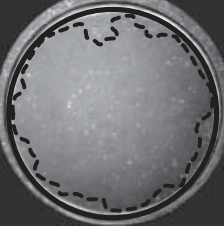

$\mathrm{t}=48 \mathrm{~h}$

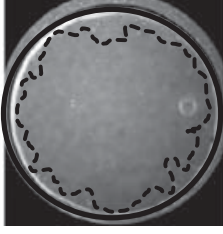

$\mathrm{t}=72 \mathrm{~h}$

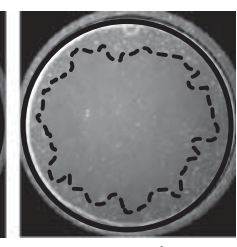

$\mathrm{t}=96 \mathrm{~h}$
Table 1. $\mathrm{p}$ values for each experimental design comparing polihexanide treatment and control

\begin{tabular}{llc}
\hline Group & Characteristics & p value \\
\hline a & $0.5 \mu \mathrm{g} / \mathrm{ml} / 1 \mathrm{~h} /$ medium exchange $48 \mathrm{~h}$ & $<0.001$ \\
$\mathrm{~b}$ & $0.5 \mu \mathrm{g} / \mathrm{ml} / 96 \mathrm{~h} /$ medium exchange $60 \mathrm{~h}$ & $<0.001$ \\
$\mathrm{c}$ & $0.5 \mu \mathrm{g} / \mathrm{ml} / 96 \mathrm{~h} /$ medium exchange $48 \mathrm{~h}$ & $<0.003$ \\
$\mathrm{~d}$ & $1 \mu \mathrm{g} / \mathrm{ml} / 1 \mathrm{~h} / \mathrm{medium}$ exchange $48 \mathrm{~h}$ & $<0.006$ \\
$\mathrm{e}$ & $1 \mu \mathrm{g} / \mathrm{ml} / 96 \mathrm{~h} /$ medium exchange $60 \mathrm{~h}$ & 0.92 \\
\hline
\end{tabular}

(3) addition of 2.0-3.0 $\mathrm{ml}$ of trypsin-EDTA solution to the flask and observation of cells under an inverted microscope until the cell layer was dispersed (usually within 5-15 min);

(4) addition of $6.0-8.0 \mathrm{ml}$ of complete growth medium and aspiration of cells by gently pipetting;

(5) addition of appropriate aliquots of the cell suspension to new precoated culture vessels. An inoculum of $4 \times 10^{3}$ to $8 \times 10^{3}$ viable cells $/ \mathrm{cm}^{2}$ is recommended. Do not exceed $1 \times 10^{5}$ cells/ $\mathrm{cm}^{2}$;

(6) incubate cultures at $37^{\circ} \mathrm{C}$.

Two to three times per week the medium was exchanged and cells were split.

\section{Statistics}

The wound areas were determined by using an analyzing tool of Photoshop CS5 software (Adobe, San Jose, Calif., USA) at a magnification of $\times 4$ on an inverted microscope (Nikon Eclipse). Two independent blinded observers assessed the wound measurements. Treatment effects were assessed using analysis of variance for repeated measurements. Each of the different groups was tested against the control group. Interaction effects of the factors group and time were considered statistically significant for $\mathrm{p}<$ 0.05. Sphericity was assumed.

\section{Results}

Considering the parameters area and radius, the statistical analysis indicated a higher sensitivity of the measured area to evaluate treatment effects compared with the radius on the residual wound diameter (data not shown). Therefore, all further calculations were performed employing wound areas.

In experiment 1 ( $\mathrm{n}=3$ per concentration), calculation of the level of significance was waived due to the small number of observations in this pilot study. On descriptive analysis, the concentrations of $2,1,0.5$ and $0.25 \mu \mathrm{g} / \mathrm{ml}$ (exposure time of $96 \mathrm{~h}$ ) stimulated wound healing in comparison to controls (fig. 3), 0.0625 and $4 \mu \mathrm{g} / \mathrm{ml}$ delayed wound healing and concentrations of $\geq 8 \mu \mathrm{g} / \mathrm{ml}$ even induced apoptosis (fig. 3 ).

In experiment 2 ( $\mathrm{n}=6$ per concentration), the 2 selected concentrations stimulated wound healing depending on the group (fig. 4). Table 1 shows the experimental design characterized by the employed concentrations of polihexanide, duration of exposure and frequency of medium exchange with the level of significance after application of analysis of variance. The concentration of 0.5 $\mu \mathrm{g} / \mathrm{ml}$ significantly stimulated the wound healing in all groups (table 1). Differences in the level of significance were only observed after application of $1 \mu \mathrm{g} / \mathrm{ml}$ with a significant difference after exposure for $96 \mathrm{~h}$ and with medium exchange after $60 \mathrm{~h}$.

In both experiments, wound healing of the standardized wounds was observed in a concentrical fashion. Close to the wound borders, the epithelial cover showed complete integrity without obvious differences in cell density in comparison to the previously uninjured monolayer. 
Fig. 3. Pilot study for the detection of optimal effects of polihexanide.
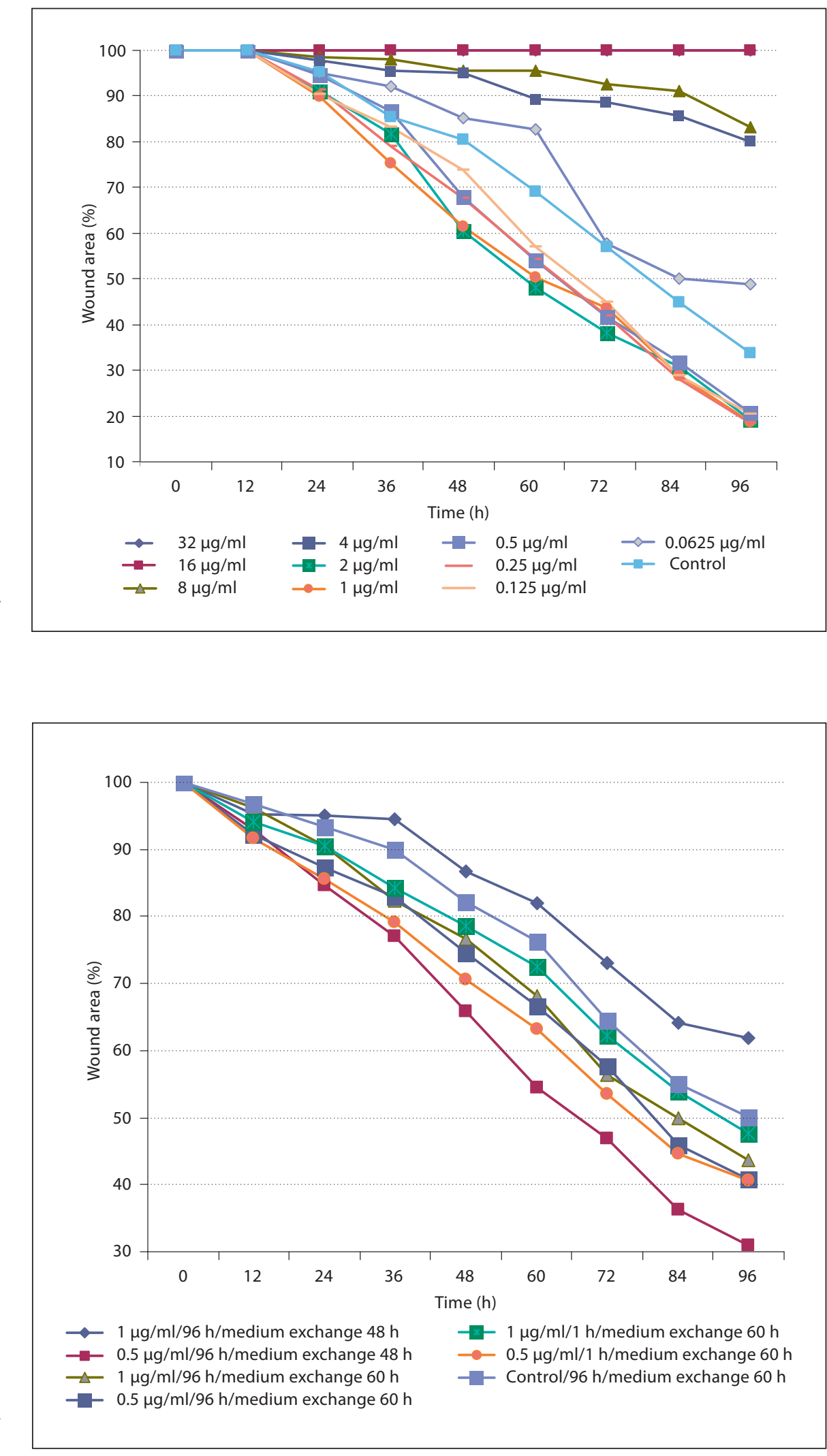

Fig. 4. Effect of 0.5 and $1 \mu \mathrm{g} / \mathrm{ml}$ polihexanide on wound healing. 


\section{Discussion}

This is the first study to demonstrate the acceleration of wound healing in a standardized in vitro model using an epithelial cell line. Interaction of polihexanide and wound healing could be shown in a dose-dependent manner with a maximum at a concentration of $0.5 \mu \mathrm{g} /$ $\mathrm{ml}$. Surprisingly, no additional effect could be observed for prolonged ( $96 \mathrm{~h}$ ) in comparison to short ( $1 \mathrm{~h}$ ) exposure time to polihexanide $0.5 \mu \mathrm{g} / \mathrm{ml}$. The lack of an additional effect on wound healing after prolonged treatment with polihexanide at $0.5 \mu \mathrm{g} / \mathrm{ml}$ suggests an immediately remanent attachment of polihexanide on cellular surfaces with following molecular reaction. To evaluate the precise mechanism of interaction, analysis of the molecular function/effect in further studies will be necessary. The missing difference between the whole time exposure and $1 \mathrm{~h}$ treatment by $1 \mu \mathrm{g} / \mathrm{ml}$ polihexanide cannot be explained.

The model employed in this study simulates a standardized wound of the upper airway in analogy to the postoperative situation. Postoperative defects left for secondary healing may result from surgery for both neoplastic and inflammatory disorders. Common examples in the upper aerodigestive region include chronic sinusitis (prevalence: 5\%) [12] and chronic tonsillitis (prevalence $7.5 \%$ ) [13]. Both sinus surgery and tonsillectomy are consecutively among the top 10 surgical procedures performed in otorhinolaryngology departments in Germany $[14,15]$. While the ultimate pathophysiological cause for rhinosinusitis and chronic tonsillitis is unknown, biofilms have been discussed as an underlying mechanism [16]. Therefore, efficient preoperative antisepsis is mandatory and even postoperative antiseptic treatment, for example with polihexanide, may be beneficial.

Wounds left for secondary healing may be colonized by bacteria, leading to deterioration of the healing process. After tonsillectomy, infection is believed to be a possible risk factor for postoperative bleeding [17]. After sinus surgery, $10-20 \%$ of patients suffer from recurrence despite adequate treatment, due to scarring and restenosis of sinus ostia [18]. Restenosis is attributed to accelerated fibroblast proliferation $[11,19,20]$. As demonstrated above, polihexanide accelerates epithelial wound healing, which may reduce both the risk of restenosis after sinus surgery and the risk of postoperative bleeding after tonsillectomy while improving postoperative outcome.

Based on the presented results, $0.5 \mu \mathrm{g} / \mathrm{ml}$ polihexanide is the determined concentration that can be recommended for acceleration of wound healing, since $1 \mu \mathrm{g} / \mathrm{ml}$ con- centration of polihexanide stimulated wound healing only in one group.

Similar to growth stimulation of keratinocytes in the monolayer cell culture [5], artificial wounds of respiratory ciliary epithelial cells close earlier under the influence of polihexanide than the control. However, the results are not directly comparable to those in the monolayer cell culture, because of the longer exposure in the wound model than in the monolayer culture and their different endpoints (i.e. wound closure by cell proliferation and ATP production in monolayer). As a consequence of the longer exposure time in the wound model, the stimulation by $1 \mu \mathrm{g} / \mathrm{ml}$ is slightly noticeable whereas only the concentration of $0.5 \mu \mathrm{g} / \mathrm{ml}$ markedly stimulated the wound healing after $1 \mathrm{~h}$ and after $96 \mathrm{~h}$ of exposure duration. This correlates with the range of concentrations in that polihexanide stimulates the production of $\operatorname{ATP}(0.2,0.4$ and $1 \mu \mathrm{g} / \mathrm{ml})$.

Concentrically oriented wound healing has previously been reported in both animal models of sinus mucosa [21] and in in vitro models [11]. Increased velocity of wound healing measured by the remaining wound area could be caused by accelerated migration of cells into the denuded area, as well as by increased cell proliferation. As we were unable to observe a difference in cell density between previously injured and uninjured areas, it seems that polihexanide stimulates both components of wound healing.

The recommended concentration of polihexanide for antiseptic usage on wounds $(0.01-0.06 \%)$ is markedly higher than applied in this in vitro wound model, raising the question how relevant the results of our wound models are with regard to clinical antiseptic application of polihexanide. Polihexanide $(0.04 \%)$ improves wound healing even in uninfected wounds $[1,2]$, indicating that the beneficial effect on wounds is independent from and additional to its antiseptic effect.

The following aspects may contribute to a markedly reduced concentration reaching the wound area and stimulating regeneration of cells: no absorption could be demonstrated for polihexanide after topical application, indicting a superficial localization of the active substance. Similarly to octenidine [22], polihexanide is strongly bound to cell surfaces, demonstrated by affinity within the oral cavity [23] as well as in vitro (unpublished). As a consequence of equilibrium reaction, it is set free slowly. Under this aspect, the stimulation of wound healing in animals as well as in chronic human wounds [24-26] is based on increasing cell proliferation and migration induced by polihexanide.

Skin Pharmacol Physiol 2010;23(suppl 1):35-40 


\section{Conclusion}

The reported stimulation of cell growth by polihexanide in keratinocytes [5] could be confirmed by our observations in respiratory ciliary epithelial cells. This effect varies depending on the duration of exposure and concentration of polihexanide applied. A dose of $0.5 \mu \mathrm{g} /$ $\mathrm{ml}$ has been identified as an optimal stimulation. Thus polihexanide is still the only well-known antiseptic which combines antimicrobial effectiveness with stimulation of wound healing.

\section{Disclosure Statement}

The authors declare that they have no stocks or stocks options related to any company manufacturing commercially available products on the basis of polihexanide as ingredient. The authors received financial support to perform this project. Prof. Axel Kramer received consulting fees from B. Braun and has a patent pending for a medical device that utilizes polihexanide as active agent. Prof. Axel Kramer received financial support as a clinical investigator for B. Braun, Lohmann \& Rauscher, Serag-Wiesner and Fresenius.

\section{References}

1 Kallenberger A, Kallenberger C, Willenegger $\mathrm{H}$ : Experimentelle Untersuchungen zur Gewebeverträglichkeit von Antiseptika. Hyg Med 1991:383-395.

- Kramer A, Roth B, Müller G, Rudolph P, Klöcker N: Influence of the antiseptic agents polihexanide and octenidine on FL cells and on healing of experimental superficial aseptic wounds in piglets. A double-blind, randomised, stratified, controlled, parallelgroup study. Skin Pharmacol Physiol 2004; 17:141-146.

- 3 Kramer A, Adrian V, Rudolph P, Wurster S, Lippert H: Explant test with skin and peritoneum of the neonatal rat as a predictive test of tolerance of local anti-infective agents in wounds and body cavities. Chirurg 1998;69: 840-845.

4 Kramer A, Reichwagen S, Below H, Heldt P, Weber U, Widulle H, Nürnberg W: Alkohole; in Kramer A, Assadian O (eds): Wallhäussers Praxis der Sterilisation, Desinfektion, Antiseptik und Konservierung. Stuttgart, Thieme, 2008, pp 643-669.

5 Wiegand C, Abel M, Kramer. A, Müller G, Ruth P, Hipler UC: Stimulation of proliferation and biocompatibility of polihexanide. GMS Krankenhaushyg Interdiszip 2007; 2:Doc43.

66 Daeschlein G, Assadian O, Bruck JC, Meinl C, Kramer A, Koch S: Feasibility and clinical applicability of polihexanide for treatment of second-degree burn wounds. Skin Pharmacol Physiol 2007;20:292-296.

7 Valenzuela A, Perucho N: Clinical evaluation of the efficacy of $0.1 \%$ polyhexanide gel (Prontosanh Wound Gel) versus the GNEAUPP and AHCPR recommendations for cleaning and debridement in the control of bacterial burden in chronic wounds. Ref Enferm 2008;31:7-12.

8 Roth B, Kramer A: Supportive antiseptic therapy of chronic ulcus cruris with polihexanide. GMS Krankenhaushyg Interdiszip 2009;4:Doc16(20091216).
9 Wiegand C, Abel M, Ruth P, Hipler U: Protective effect of polihexanide on HaCaT keratinocytes in co-culture with staphylococcus aureus. EWMA J 2008;8(Suppl 2):178.

10 Müller G, Kramer A: Biocompatibility index of antiseptic agents by parallel assessment of antimicrobial activity and cellular cytotoxicity. J Antimicrob Chemother 2008;61: 1281-1287.

11 Beule AG, Athanasiadis T, Field J, Hosemann W, Wormald PJ, Tan LW: Effects of simulated bleeding in an in vitro nasal fibroblast wound healing model. Am J Rhinol Allergy 2010;24:186-191.

12 Fokkens W, Lund V, Mullol J: European position paper on rhinosinusitis and nasal polyps 2007. Rhinol Suppl 2007;20:1-136.

13 Mattila PS, Tahkokallio O, Tarkkanen J, Pitkäniemi J, Karvonen M, Tuomilehto J: Causes of tonsillar disease and frequency of tonsillectomy operations. Arch Otolaryngol Head Neck Surg 2001:127:37-44.

14 Franz D, Roeder N, Alberty J: DRG Evaluationsprojekt Hals-Nasen-Ohren-Heilkunde, Kopf- und Hals-Chirurgie: Abbildungsqualität stationärer Therapien der Hals-NasenOhren-Heilkunde, Kopf- und Hals-Chirurgie und Anpassungsbedarf des G-DRGSystems. Münster, Schüling, 2005.

15 Beule AG, Hosemann W: Wundheilung und postoperative Behandlung nach Nasennebenhöhlenoperationen. HNO 2009;57:763771.

16 Fokkens WJ EF, van Drunen CM: Fungus: a role in pathophysiology of chronic rhinosinusitis, disease modifier, a treatment target, or no role at all? Immunol Allergy Clin North Am 2009;29:677-688.

17 Beule A, Hosemann W: Bakterielle Biofilme. Laryngorhinootologie 2007;86:886-899.

18 Schrock A, Send T, Heukamp L, Gerstner AO, Bootz F, Jakob M: The role of histology and other risk factors for post-tonsillectomy haemorrhage. Eur Arch Otorhinolaryngol 2009;266:1983-1987.
19 Beule AG, Scharf C, Biebler KE, Göpferich A, Steinmeier E, Wolf E, Hosemann W, Kaftan $\mathrm{H}$ : Effects of topically applied dexamethasone on mucosal wound healing using a drug-releasing stent. Laryngoscope 2008; 118:2073-2077.

20 Beule AG, Steinmeier E, Kaftan H, Biebler KE, Göpferich A, Wolf E, Hosemann W: Effects of a dexamethasone-releasing stent on osteoneogenesis in a rabbit model. Am J Rhinol Allergy 2009;23:433-436.

21 Beule AG, ScharfC, Biebler KE, Göpferich A, Steinmeier E, Wolf E, Hosemann W, Kaftan $\mathrm{H}$ : Effects of topically applied dexamethasone on mucosal wound healing using a drug-releasing stent. Laryngoscope 2008; 118:2073-2077.

22 Rosin M, Welk A, Bernhardt O, Ruhnau M, Pitten FA, Kocher T, Kramer A: Effect of a polyhexamethylene biguanide mouthrinse on bacterial counts and plaque. J Clin Periodontol 2001;28:1121-1126.

23 Müller G, Kramer A: Interaction of octenidine and chlorhexidine with mammalian cells and the resulting microbicidal effect (remanence) of the combinations. GMS Krankenhaushyg Interdiszip 2007;2:Doc46 (20071228).

24 Schmit-Neuerburg K, Bettag C, Schlickewei W, Fabry W, Hanke J, Renzig-Köhler K, Hirche H, Kock HJ: Wirksamkeit eines neuartigen Antisepticum in der Behandlung kontaminierter Weichteilwunden. Chirurg 2001;72:61-71.

25 Roth B, Assadian O, Wurmitzer F, Kramer A: Surgical site infections after primary antiseptic cleansing of dirty-contaminated wounds by polihexanide, PVP iodine resp hydrogen peroxide. GMS Krankenhaushyg Interdiszip 2007;2:Doc58(20071228).

26 Andriessen A, Eberlein T: Assessment of a wound cleansing solution in the treatment of problem wounds. Wounds 2008;20:171-175. 